\title{
Сдобное печенье повышенной пищевой ценности
}

\author{
Алексеенко Елена Викторовна \\ ФГБОУ ВО «Московский Государственный Университет пищевых производств» \\ Адрес: 125080, г. Москва, Волоколамское шоссе, д. 11 \\ E-mail: AlekseenkoEV@mgupp.ru \\ Белявская Ирина Георгиевна \\ ФГБОУ ВО «Московский Государственный Университет пищевых производств» \\ Адрес: 125080, г. Москва, Волоколамское шоссе, д. 11 \\ E-mail: Belyavskaya@mgupp.ru
}

Зайцева Лариса Валентиновна Всероссийский научно-исследовательский институт кондитерской промышленности - филиал ФГБУН «ФНЦ пищевых систем им. В.М. Горбатова» $P A H$ Адрес: 107023, г. Москва, ул. Электрозаводская, д. 20, стр.3 E-mail: lvz2360@mail.ru

Уварова Анна Георгиевна ФГБОУ ВО «Курская государственная сельскохозяйственная академия имени И.И. Иванова» Адрес: 305021, г. Курск, ул. Карла Маркса, д. 70 E-mail: A.G.Uvarova@yandex.ru

\begin{abstract}
Приоритетным направлением в разработке новых видов сдобного печенья является модификация традиционных рецептур и использование инновационных ингредиентов, обеспечивающих повышение пищевой ценности готовых изделий и формирующих их функциональную направленность. Проведен комплекс исследований по экспериментальному обоснованию, разработке рецептуры и технологических решений с целью получения сдобного печенья повышенной пищевой ценности на основе муки пшеничной из цельносмолотого зерна и жирового продукта энзимной переэтерификации с омега-3 жирными кислотами с добавлением микроводоросли спирулины. Изучено влияние выбранных ингредиентов на органолептические, физико-химические показатели и пищевую ценность готовых изделий. Показано, что разработанный вид сдобного печенья имеет достойные потребительские свойства, по физико-химическим показателям - соответствует требованиям ГОСТ 24901-2014 при некотором снижении показателя намокаемости. Доказано, что разработанное изделие характеризуется улучшенным липидным профилем: в составе жирных кислот содержится значительное количество ненасыщенных жирных кислот (55\%) по сравнению со сдобным печеньем, полученным по традиционной рецептуре, выявлено наличие $\gamma$-линоленовой кислоты, отмечается десятикратное увеличение содержания эссенциальной линолевой кислоты; печенье может быть позиционировано как изделие, являющееся источником незаменимых омега-3 жирных кислот (альфа-линоленовой более 0,2 г/100 г). Установлено, что сдобное печенье, полученное по усовершенствованной рецептуре, является источником пищевых волокон (5,87 г/100 г продукта), магния (20\% средней суточной потребности на 100 г) и железа (23\% средней суточной потребности на 100 г) при низком содержании натрия (соли) (42,3 мг/100г). Разработан комплект ТД (ТУ, ТИ) (проект) на новое обогащенное сдобное печенье.
\end{abstract}

Ключевые слова: сдобное печенье, мука пшеничная из цельносмолотого зерна, жировой продукт энзимной переэтерификации, спирулина, органолептические и физико-химические показатели, пищевая ценность

\section{Введение}

Мучные кондитерские изделия находятся в сегменте особых потребительских предпочтений.
Изделия отличаются приятным вкусом, привлекательным внешним видом и представлены в широком ассортименте: печенье, галеты, кексы, вафли, пряники и другие. 
Производство и потребление мучных кондитерских изделий в Российской Федерации неуклонно растет. По данным Росстата индекс потребления мучных кондитерских изделий достиг 25,2 кг на человека, и на период с 2019 по 2023 гг. в России ожидается дальнейший рост их производства примерно на 1,8 - 2,3\% в год. Причем, из ассортимента мучных кондитерских изделий прогнозируется ощутимый рост производства печенья, которое является наиболее доступным в ценовой категории кондитерским изделием. По мнению экспертов, производство данной категории продукции также будет увеличиваться за счет расширения ее ассортимента, на формирование которого будет оказывать влияние возрастающий с каждым годом спрос на продукты здорового питания, мотивирующие отрасль на выпуск изделий с пониженным содержанием критически значимых ингредиентов - жиров, сахаров, соли и обогащенных полезными для здоровья человека эссенциальными и минорными компонентами, что отвечает целям Стратегии формирования здорового образа жизни населения, профилактики и контроля неинфекционных заболеваний на период до 2025 г. ${ }^{1}$ и Стратегии повышения качества пищевой продукции в Российской Федерации до 2030 г. ${ }^{2}$, утвержденных Правительством РФ.

Анализ научно-технической литературы и патентных источников показывает, что доминирующим направлением в разработке новых сортов мучных кондитерских изделий, в том числе сдобного печенья, является модификация традиционных рецептур и использование инновационных ингредиентов, обеспечивающих повышение пищевой ценности готовых изделий и формирующих их функциональную направленность (Резниченко \& Устинова, 2020). Разработки в этом направлении развиваются по пути частичной или полной замены основных рецептурных ингредиентов - муки пшеничной высшего сорта и жировой основы альтернативными ингредиентами (Магомедов, Малютина, Зацепилина, Шапкарина, \& Лыгин, 2016; Лаптева \& Митькиных, 2013) и дополнительного введения в состав рецептуры обогащающих компонентов растительного происхождения и биологически активных добавок. Вместе с этим решаются вопросы, касающиеся продления сроков годности мучных кондитерских изделий и сохранения их свежести (Журав- ская \& Васюкова, 2019; Шпис А. А. \& Шпис А. Н, 2016; Назимова, Захаренко, \& Марков, 2020; Шабурова \& Кулькова, 2019; Захарова, Козубаева, Егорова, 2019; Захарова, Кузьмина, \& Егорова, 2020).

Продемонстрирована возможность полной замены пшеничной муки тритикалевой мукой в производстве песочно-сдобного печенья (Магомедов, Малютина, Зацепилина, Шапкарина, \& Лыгин, 2016). Разработанные изделия имели высокие потребительские свойства и функциональную направленность.

Выявлено оптимальное соотношение муки пшеничной высшего сорта, ржаной обдирной и тритикалевой (50:30:20 и 40:30:30) в производстве сдобного печенья типа «Лимонное» (Лаптева, 2013, с. 35). Установлено повышение пищевой ценности полученных изделий (по содержанию пищевых волокон, минеральных веществ - калия, магния, железа) и биологической ценности (по содержанию незаменимых аминокислот - лизина, валина, треонина).

Разработаны композитные смеси на основе пшеничной муки высшего сорта, пшенной и гречневой муки при производстве сдобного печенья (Хлюдзинская, 2019). Показано, что пшенная и гречневая мука влияют на органолептические свойства продукта. Введение в состав рецептуры пшенной муки позволяет получить продукт с рыхлой текстурой, а использование гречневой муки наделяет продукт более выраженным ароматом и вкусом. Установлено, что гречневая мука замедляет процессы черствения печенья и увеличивает сроки его хранения.

Перспективы применения гречневой муки при производстве печенья сдобного продемонстрированы в работе (Иванова, 2019). Показано, что по органолептическим и физико-химическим показателям лучшими признаны образцы печенья с 10 и 30\% заменой муки пшеничной на муку гречневую.

Разработана рецептура сдобного печенья функционального назначения, включающая смесь муки пшеничной и каштановой в соотношении 4:1, позволяющая получить продукт с повышенной пищевой ценностью и улучшенными органолептическими показателями ${ }^{3}$.

\footnotetext{
1 Приказ Министерства здравоохранения РФ от 15 января 2020 г. N 8 «Об утверждении Стратегии формирования здорового образа жизни населения, профилактики и контроля неинфекционных заболеваний на период до 2025 года» URL: https://www. garant.ru/products/ipo/prime/doc/73421912/ (дата обращения: 15.05.2021)

2 Распоряжение Правительства РФ от 29.06.2016 N 1364-р “Об утверждении Стратегии повышения качества пищевой продукции в Российской Федерации до 2030 года” URL: https://docs.cntd.ru/document/420363999 (дата обращения: 15.05.2021)

3 Болгова, Д. Ю., \& Тарасенко, Н. А. (2017). РФ Патент № 2616788. Сдобное печенье функционального назначения.
} 
Разработан способ приготовления тестовой массы для изготовления печенья сложной рецептуры на основе смеси из пшеничной и спельтовой муки (Бессмертная, \& Васильченко, 2018). Представлена технологическая схема производства продукта.

С применением методов математического планирования разработана рецептура сдобного печенья на основе муки тритикалевой обдирной и муки из проростков семян нута (Тертычная, Мажулина, Горбунова, \& Синельникова, 2019). Готовый продукт отличается повышенным содержанием белка, пищевых волокон, минеральных веществ, витаминов и может быть рекомендован для лечебно-профилактических целей.

Представлены результаты исследований по применению кедровой обезжиренной муки в количестве 20\% (Кузьмина, Козубаева, \& Гайсина, 2015) и подсолнечной муки из жмыха в количестве $17 \%$ взамен пшеничной муки при производстве сдобного печенья (Гайсина, Козубаева, \& Кузьмина, 2017). Показано, что использование нетрадиционных ингредиентов позволяет получить продукт с достойными потребительскими свойствами и повышенной пищевой ценностью по содержанию белка, пищевых волокон и др.

Большое внимание уделяется разработке новых видов сдобного печенья с использованием плодово-ягодного и овощного сырья регионального значения и продуктов их переработки - ягод брусники и плодов ирги (Захарова, Козубаева, \& Егорова, 2019; Захарова, Кузьмина, \& Егорова, 2020), порошка ягод шиповника (Назимова, Захаренко, \& Марков 2020), клюквы и черной смородины (Меренкова \& Полякова, 2018; Колбина, 2018), облепихи (Шпис А. А. \& Шпис, А. Н., 2016); плодов черемухи (Захарова, Кузьмина, \& Егорова, 2020), боярышника и топинамбура (Дерканосова, Курчаева, Пащенко, \& Калашникова, 2018), виноградных выжимок (Клочко, Короткова, Ксандопуло 2017). Авторы отмечают, что разработанные изделия имеют привлекательный внешний вид, приятный вкус и аромат. Применение натуральных растительных добавок позволяет существенно улучшить пищевой профиль готовых изделий при обеспечении регламентируемых физико-химических показателей качества.

Широкий спектр исследований проводится в сфере разработок рецептур сдобного печенья с применением пищевых волокон, результаты которых убедительно демонстрируют перспективность этого направления. Доказана целесообразность использования в качестве рецептурных ингредиентов отрубей пшеничных, ржаных, овсяных (Журавская
\& Васюкова, 2019)]. Показана возможность расширения ассортимента песочно-выемного сдобного печенья на основе замены 20\% пшеничной муки на муку овсяных отрубей и применения порошка мякоти тыквы, что позволяет сократить количество сахарной пудры в рецептуре печенья на 20\% (Шабурова \& Кулькова, 2019). Разработана рецептура с использованием инулин содержащего сырья (пюре топинамбура) (Киселева \& Насырова, 2017). Показано, что применение пектина и полуобезжиренной муки из семян тыквы в количестве 1,4 и 20\% к общей массе муки в рецептурной смеси сдобного печенья придает изделию необходимую разрыхленность, позволяет повысить содержание белка, пищевых волокон, минеральных веществ, каротиноидов (Калинкина \& Егорова, 2019).

Таким образом, представленные в литературе сведения демонстрируют перспективные направления в развитии технологий сдобного печенья, ориентированные на использование нетрадиционных ингредиентов, нативный состав и функционально-технологические свойства которых позволяют создавать изделия с высокими потребительскими характеристиками, повышенной пищевой и биологической ценности, пониженной калорийности и профилактической направленности.

\section{Теоретическое обоснование}

В структуре кондитерского рынка сдобное печенье занимает лидирующие позиции. Потребительская привлекательность этой категории мучных кондитерских изделий обусловливает высокий спрос на нее со стороны различных слоев населения.

Проведенный анализ литературных источников позволил выявить приоритетные направления в совершенствовании технологий сдобного печенья. Одним из эффективных технологических приемов является модификация рецептурного состава сдобного печенья, направленная на гармонизацию потребительских свойств изделия, критериев безопасности, пищевой и биологической ценности.

Традиционная рецептура сдобного печенья предполагает использование классических ингредиентов, среди которых наиболее значимыми в количественном отношении являются мука пшеничная высшего сорта и жировой продукт. Поэтому при усовершенствовании рецептуры целесообразно варьировать именно этими ингредиентами.

В ряде работ продемонстрирована возможность замены части пшеничной муки высшего сорта аль- 
тернативным сырьем - цельнозерновой мукой, которую получают путем однократного измельчения зерна злаковых культур без дальнейшего его просеивания. Такой способ обработки зерна позволяет более полно сохранить в муке пищевые компоненты, содержащиеся в оболочке зерна- пищевые волокна, белок, минеральные вещества, витамины (Матвеева, Юдина, Дешко, \& Дудник, 2011).

Установлена целесообразность применения смесей муки пшеничной высшего сорта и цельнозерновой разных видов при производстве сахарного печенья, что позволяет увеличить в готовых изделиях содержание пищевых волокон, белка и фосфора в 1,5-2,0 раза, магния - почти в 30 раз. Разработана рецептура сахарного печенья для детского питания, обеспечивающая получение продукта с содержанием жира менее $18 \%$, сахара - менее $22 \%$, соли - менее 0,3 г/100 г, пищевых волокон - более 3,0 г/100 г (Талейсник, Щербакова, Герасимов, \& Мизинчикова, 2019).

Рассмотрена возможность использования цельнозерновой пшеничной муки, а также отрубей (пшеничных, овсяных, ржаных) при производстве мучных кондитерских изделий (Могильный \& Шалтумаев, 2017). Выявлено положительное влияние применяемых ингредиентов на процессы черствения и усыхания при хранении готовых изделий: установлено, что изделия теряют влагу в среднем на 30 - 35\% меньше по сравнению с традиционными технологиями.

В технологии песочно-сдобного печенья предложено использовать тритикалевую муку сеяную сорта «Укро» и муку из цельносмолотого зерна тритикале сорта «Укро» (Магомедов, Малютина, Зацепилина, Шапкарина, \& Лыгин, 2016). Разработанные изделия характеризуются высокими потребительскими свойствами и функциональной направленностью.

Перспективным ингредиентом при производстве сдобного печенья следует рассматривать жировой продукт энзимной переэтерификации растительных масел, содержащий омега-3 жирные кислоты. При этом способе модификации растительных масел изменяется консистенция конечного продукта при сохранении его жирнокислотного состава и токоферолов, удается избежать накопления атерогенных транс-изомеров жирных кислот, приводящих к возникновению сердечно-сосудистых, онкологических и других заболеваний, гарантируется полная безопасность и экологическая чистота. При энзимной переэтерификации создаются оптимальные условия для обогащения масложирового продукта эссенциальными жирными кислотами, включая дефицитные для россиян омега-3 жирные кислоты.

Масложировой продукт энзимной переэтерификации, содержащий омега-3 жирные кислоты, успешно апробирован при производстве хлебобулочных и мучных кондитерских изделий, включая изделия специализированной направленности (Зайцева, Белявская, \& Юдина, 2013; Зайцева, Юдина, \& Рубан 2017; Зайцева, Юдина, Рубан, Бессонов, \& Мехтиев, 2020; Матвеева \& Корячкина, 2009; Цыганова, Нечаев, Зайцева, Грекова, \& Иовлева, 2016). Установлено, что готовые изделия характеризуются улучшенным пищевым профилем, физико-химическими и органолептическими показателями качества, более длительными сроками годности.

В пищевой индустрии успешно развивается направление, аккумулирующее полезные свойства спирулины как биологически активной добавки и реализуемое в технологиях продуктов питания (Smertina, Fedyanina, Lyakh, Chadova, \& Vershinina 2016; Soni, Sudhakar, \& Rana, 2017; Morsy, Sharoba, EL-Desouky, Bahlol, \& Abd El Mawla, 2014).

Микроскопическая водоросль спирулина (Spirulina platensis) обладает уникальным составом и содержит комплекс полезных для здоровья человека фитонутриентов, которые могут быть использованы в технологиях продуктов питания: белковые вещества с набором эссенциальных аминокислот (до 60\% с.в), ПНЖК, в том числе, линолевая, витамины группы В, PР, токоферолы, каротиноиды, минеральные вещества (Бобылева, 2018; Petrova \& Zhateva, 2018).

Для спирулины выявлены антиоксидантные свойства (Кравченко, Гладких, \& Гмошинский, 2005) и установлено ее противовирусное действие: спирулина Spirulina platensis и её водные экстракты способны подавлять репликацию вируса иммунодефицита человека 1 типа, а также некоторых других оболочечных вирусов (Ромай, Гонсалес, Ледон, Ремирес, \& Римбау, 2003). Фармакологические эффекты компонентов спирулины, безусловно, могут быть реализованы в продуктах питания.

Продемонстрирована эффективность применения спирулины в технологиях хлебобулочных изделий функционального назначения (Белявская, 2017) и освещены перспективы ее применения как ингредиента в технологиях кондитерских изделий (Smertina, Fedyanina, Lyakh, Chadova, \& Vershinina, 2016).

Таким образом, проведенный анализ позволил аргументированно подойти к выбору рецептурных ингредиентов, применение которых при получе- 
нии сдобного печенья позволит получить продукт повышенной пищевой ценности по содержанию эссенциальных компонентов, наделить продукт полезными для здоровья свойствами и расширить ассортиментную линейку данного вида мучного кондитерского изделия.

Цель исследований - экспериментальное обоснование и разработка технологических решений по получению сдобного печенья на основе цельнозерновой пшеничной муки и жирового продукта энзимной переэтерификации, содержащего омега-3 жирные кислоты, с добавлением микроводоросли спирулины.

В соответствии с поставленной целью определены задачи исследования:

- $\quad$ изучить влияние цельнозерновой пшеничной муки и жирового продукта энзимной переэтерификации, содержащего омега-3 жирные кислоты, при использовании их в качестве рецептурных ингредиентов при получении сдобного печенья на его органолептические и физико-химические показатели;

- разработать рецептуру сдобного печенья с применением вышеназванных ингредиентов и спирулины; дать характеристику готовому изделию по органолептическим и физико-химическим показателям;

- проанализировать пищевую ценность разработанного изделия;

- разработать технологические решения и проект технической документации (ТУ, ТИ) на новое обогащенное сдобное печенье.

\section{Материалы и методы}

Исследования проводили на кафедрах «Биотехнология и технология продуктов биоорганического синтеза» и «Зерна, хлебопекарных и кондитер- ских технологий» ФГБОУ ВО «Московский государственный университет пищевых производств».

\section{Материалы}

Объектами исследования являлись образцы сдобного печенья, выпеченные в лабораторных условиях с применением муки пшеничной из цельносмолотого зерна (далее цельнозерновой муки), масложирового продукта энзимной переэтерификации, содержащего омега-3 жирные кислоты, и биологически активной добавки спирулины. В качестве контрольного образца использовали образцы сдобного печенья, полученные по традиционной рецептуре без применения вышеназванных ингредиентов.

Для проведения исследования было использовано следующее сырье: мука пшеничная хлебопекарная высшего сорта, мука пшеничная из цельносмолотого зерна СТО 00934033-017-2015; сахар белый ГОСТ 33222-20154; маргарин ГОСТ 32188-20135 , заменитель молочного жира энзимной переэтерификации с обязательным содержанием омега-3 жирных кислот по ГОСТ 31648-20126; гидрокарбонат натрия ГОСТ 32802-20147; соль пищевая ГОСТ Р 51574-2018 ; углекислый аммоний ГОСТ Р 55580-20139; вода питьевая по ГОСТ Р $51232^{10}$ или СанПиН 2.1.4.1074'11; микроводоросль Spirulina platensis сухая биомасса «СПИРУЛИНА» ТУ 9284011-17230230-15.

Органолептическую оценку выпеченных образцов сдобного печенья проводили в соответствии с ГОСТ 5897-9012. Определение показателей намокаемости - по ГОСТ 10114-8013, щелочности ГОСТ $5898-87^{14}$.

\section{Методы}

Определение массовой доли влаги проводили по ГОСТ 5900-2014 ${ }^{15}$, общего сахара - ГОСТ 5903-8916,

\footnotetext{
4 ГОСТ 33222-2015. (2019). Сахар белый. Технические условия. М.: Стандартинформ.

5 ГОСТ 32188-2013. (2014). Маргарины. Общие технические условия. М.: Стандартинформ.

6 ГОСТ 31648-2012.(2012). Заменители молочного жира. Технические условия. М.: Стандартинформ.

ГОСТ 32802-2014. (2015). Добавки пищевые. Натрия карбонаты Е500. Общие технические условия. М.: Стандартинформ

ГОСТ Р 51574-2018. (2018). Соль пищевая. Общие технические условия. М.: Стандартинформ.

ГОСТ Р 55580-2013. (2014). Добавки пищевые. Аммония карбонаты Е503. Общие технические условия. М.: Стандартинформ.

10 ГОСТ Р 51232-98. (1998). Вода питьевая. Общие требования к организации и методам контроля качества. М.: Госстандарт России.

11 СанПиН 2.1.4.1074. (2002). Питьевая вода. Гигиенические требования к качеству воды централизованных систем питьевого водоснабжения. Контроль качества. М.: Минздрав России.

12 ГОСТ 5897-90. (2012). Изделия кондитерские. Методы определения органолептических показателей качества, размеров, массы нетто и составных частей. М.: Стандартинформ.

13 ГОСТ 10114-80. (2012). Изделия кондитерские мучные. Метод определения намокаемости. М.: Стандартинформ.

14 ГОСТ 5898-87. (2012). Изделия кондитерские. Методы определения кислотности и щелочности. М.: Стандартинформ.

15 ГОСТ 5900-2014. (2019). Изделия кондитерские. Методы определения влаги и сухих веществ. М.: Стандартинформ.

16 ГОСТ 5903-89. (2012). Изделия кондитерские. Методы определения сахара. М.: Стандартинформ.
} 
Таблица 1

Рецептура сдобного песочно-выемного печенья

\begin{tabular}{lccc}
\hline \multirow{2}{*}{ Наименование сырья } & $\begin{array}{c}\text { Содержание } \\
\text { сухих веществ, \% }\end{array}$ & Расход сырья на 1 т готового продукта, кг \\
\cline { 3 - 4 } Мука пшеничная высшего сорта & 85,50 & в натуре & в сухих веществах \\
Маргарин & 84,00 & 643,51 & 550,20 \\
Сахар белый & 99,85 & 276,10 & 213,92 \\
Соль пищевая & 96,50 & 214,38 & 214,06 \\
Гидрокарбонат натрия & 50,00 & 2,40 & 2,32 \\
Углекислый аммоний & 0,00 & 2,99 & 1,50 \\
Итого: & - & 1,36 & 0,00 \\
Выход: & 95,00 & 1140,74 & 1000,00 \\
Потери, \% & - & 1000,00 & 950,00 \\
\hline
\end{tabular}

золы - ГОСТ Р 51411-99 (ИСО 2171-93) $)^{17}$, липидов по методике, изложенной в руководстве ${ }^{18}$.

Определение качественного состава жирных кислот в виде метиловых эфиров проводили методом ГЖХ в соответствии с ГОСТ 31663-2012 ${ }^{19}$, группового состава липидов по методике, изложенной в руководстве ${ }^{16}$.

Минеральный состав определяли методом атомно-эмиссионной спектроскопии с индуктивно-связанной плазмой, используя оптический эмиссионный спектрометр іCAP 6300 Duo (Thermo Fisher Scientific, США) ${ }^{20}$.

Расчет пищевой ценности образцов сдобного печенья проводили по методике, разработанной ФГАНУ НИИХП.

\section{Процедура исследования}

Для приготовления лабораторных образцов сдобного печенья в качестве базовой была выбрана рецептура сдобного песочно-выемного печенья ${ }^{21}$, представленная в Таблице 1.

Приготовление теста проводили следующим образом: предварительно размягченный при комнатной температуре жировой продукт взбивали миксером с измельченным сахаром белым (из- мельчен в ступке до однородной массы в течение $2-3$ минут). В просеянную муку вносили гидрокарбонат натрия, углекислый аммоний и пищевую соль, перемешивали в течение 1 2 минут до равномерного распределения всех компонентов.

Спирулину измельчали в ступке до порошкообразного состояния и перемешивали с питьевой водой в соотношении 1:3.

Для приготовления теста взбитую жировую массу вливали в мучную смесь. На этом этапе в экспериментальные образцы сдобного печенья добавляли суспензию спирулины. Замес теста осуществляли в течение 5-7 минут до необходимой рассыпчатой консистенции, при которой тесто не будет липнуть к рукам и легко собираться в комок.

Полученное тесто раскатывали в пласт 2 - 3 мм, вырезали формочкой полуфабрикат, после чего выпекали в печи при температуре $190-200{ }^{\circ} \mathrm{C}$ в течение 17 минут.

После выпекания готовые изделия охлаждали до комнатной температуры.

Полученные образцы оценивали по органолептическим, физико-химическим показателям и пищевой ценности.

\footnotetext{
17 ГОСТ Р 51411-99. (1999). Зерно и продукты его переработки. Определение зольности (общей золы). М.: Госстандарт России.

18 Нечаев, А. П., Дубцова, Г. Н., Алексеенко, Е. В., Суслянок, Г. М., \& Соколова, О. С. (2015). Практическое руководство к выполнению лабораторных работ по дисциплине «Пищевая химия» (Белки, липиды, углеводы). М.: ЦНТБ пищевой промышленности.

19 ГОСТ 31663-2012. (2013). Масла растительные и жиры животные. Определение методом газовой хроматографии массовой доли метиловых эфиров жирных кислот. М.: Стандартинформ.

20 Лесс, В. Р. (2011). Практическое руководство для лаборатории. Специильные методы. СПб.: Профессия.

${ }^{21}$ Кузнецова, Л. С., \& Сиданова, М. Ю. (2002). Технология приготовления кондитерских изделий: Учеб. пособие. М.: Мастерство.
} 


\section{Анализ}

Обработку результатов исследований производили с применением статистического метода обработки экспериментальных данных, определяя средние значения вычисляемой величины на основе не менее трех повторных определений.

\section{Результаты и их обсуждение}

Для изучения влияния количественной замены пшеничной муки высшего сорта мукой пшеничной цельнозерновой на показатели качества сдобного печенья проводили пробные лабораторные выпечки тестовых полуфабрикатов, в рецептуре приготовления которых варьировали содержанием пшеничной цельнозерновой муки ${ }^{22}$, состав которой представлен в Таблице 2.

Как свидетельствуют представленные результаты, мука характеризуется высоким содержанием клетчатки, белков; отличается повышенным содержанием витаминов и минеральных веществ по сравнению с мукой пшеничной высшего сорта (Таблица 2).

Замену пшеничной муки высшего сорта мукой пшеничной цельнозерновой осуществляли в количествах 25\%, 75\% и 100\%. Рецептуры тестовых полуфабрикатов представлены в Таблице 3.

Экспериментальные образцы сдобного печенья оценивали по органолептическим и физико-химическим показателям качества (Таблицы 4-5).

Как видно из полученных результатов, внесение цельнозерновой пшеничной муки влияет на такие показатели, как состояние поверхности и цвет. Данный вид муки придает шероховатость поверхности изделия за счет своей структурной особенности, а также серый оттенок, который усиливается с уве-
Таблица 2

Состав пшеничной цельнозерновой муки

\begin{tabular}{lc}
\hline \multicolumn{1}{c}{ Компонент } & Содержание, в 100 г \\
\hline & Макронутриенты, г \\
\hline белки & 14,5 \\
жиры & 1,6 \\
углеводы & 73,2 \\
\hline \multicolumn{2}{c}{ Пищевые волокна, г } \\
\hline клетчатка & 3,7 \\
\hline \multicolumn{2}{c}{ Витамины: } \\
\hline В (тиамин), мг & 0,2 \\
В (рибофлавин), мг & 0,2 \\
В, мкг & 0,4 \\
Е (альфа-токо- & 32,0 \\
ферол), мг & 30,8 \\
\hline \multicolumn{2}{c}{ Минеральные вещества: } \\
\hline кальций, мг & 5,8 \\
железо, мг & 0,5 \\
фосфор, мг &
\end{tabular}

личением ее количества в составе рецептуры (Таблица 4). На показатели «форма» и «вид в изломе» внесение цельнозерновой пшеничной муки никак не отразилось: полученные образцы сохраняли форму независимо от количества внесенной цельнозерновой муки и идеально пропекались, не имея дефектов. Вкус и запах, свойственный цельнозерновой пшеничной муке, усиливался с увеличением ее содержания в рецептуре теста (Таблица 4).

Анализ физико-химических показателей экспериментальных образцов сдобного печенья показал, что замена пшеничной муки высшего сорта на цельнозерновую муку в рецептуре сдобного печенья приводит к снижению показателя намокаемости (в абсолютном выражении на 12-53\% относительно контроля), которое напрямую коррелирует с количеством внесенной цельнозерновой муки. Показатель намокаемости - важный показатель качества изделия, характеризующий его внутреннюю струк-

Таблица 3

Соотношение сортов пшеничной муки в экспериментальных образцах сдобного печенья

\begin{tabular}{|c|c|c|c|c|}
\hline \multirow{2}{*}{$\begin{array}{l}\text { Расход сырья на } 100 \text { г } \\
\text { готовой продукции, г }\end{array}$} & \multirow{2}{*}{$\begin{array}{c}\text { Контрольный образец } \\
\text { (по традиционной рецептуре) }\end{array}$} & \multicolumn{3}{|c|}{ Образцы с использованием цельнозерновой муки } \\
\hline & & $\begin{array}{c}\text { Замена 25\% } \\
\text { муки в/с }\end{array}$ & $\begin{array}{c}\text { Замена } 75 \% \\
\text { муки в/с }\end{array}$ & $\begin{array}{c}\text { Полная } \\
\text { замена муки в/с }\end{array}$ \\
\hline $\begin{array}{l}\text { Мука пшеничная } \\
\text { высшего сорта }\end{array}$ & 64,35 & 48,26 & 19,09 & 0,00 \\
\hline $\begin{array}{l}\text { Мука пшеничная } \\
\text { цельнозерновая }\end{array}$ & 0,00 & 16,09 & 48,26 & 64,35 \\
\hline
\end{tabular}

\footnotetext{
${ }^{22}$ Химический состав российских пищевых продуктов: Справочник. (2002). (Ред.) И. М. Скурихина, В. А. Тутельяна. М: ДеЛи принт.
} 
Таблица 4

Органолептические показатели образцов сдобного печенья с использованием цельнозерновой пшеничной муки

\begin{tabular}{|c|c|c|c|c|}
\hline \multirow[b]{2}{*}{ Показатель } & \multirow{2}{*}{$\begin{array}{l}\text { Контрольный образец (по } \\
\text { традиционной рецептуре) }\end{array}$} & \multicolumn{3}{|c|}{ Образцы с использованием цельнозерновой муки } \\
\hline & & $\begin{array}{c}\text { Замена } 25 \% \\
\text { муки в/с }\end{array}$ & $\begin{array}{c}\text { Замена } 75 \% \\
\text { муки в/с }\end{array}$ & $\begin{array}{c}\text { Полная } \\
\text { замена муки в/с }\end{array}$ \\
\hline Форма & \multicolumn{4}{|c|}{ Не расплывчатая, без повреждений } \\
\hline Поверхность & Гладкая & Слегка шероховатая & \multicolumn{2}{|c|}{ Шероховатая } \\
\hline Цвет & $\begin{array}{c}\text { Равномерный, } \\
\text { светло-соломенный }\end{array}$ & Равномерный, светло-серый & \multicolumn{2}{|c|}{ Равномерный, серый } \\
\hline Вкус и запах & \multicolumn{4}{|c|}{ Соответствуют вкусу и запаху рецептурных компонентов } \\
\hline Вид в изломе & \multicolumn{4}{|c|}{ Пропеченное, имеет пористую структуру } \\
\hline
\end{tabular}

туру и обусловливающий такие свойства как гигроскопичность и пористость. Снижение намокаемости свидетельствует о более плотной структуре печенья, что, по всей видимости, можно объяснить использованием цельнозерновой муки, содержащей значительные количества грубых пищевых волокон, а также водо- и солерастворимых белков.

Показатели щелочности и массовой доли влаги не превышают регламентируемых значений (Таблица 5).

Респонденты (15 человек в возрасте от 21 до 25 лет), участвующие в дегустации, дали высокую оценку экспериментальным образцам печенья со $100 \%$ заменой муки в/с по показателям вкуса, цвета, запаха и внешнего вида, оценив их с контрольным образцом.

Таким образом, замена пшеничной муки высшего сорта на цельнозерновую позволяет сохранить высокие потребительские свойства готовых изделий, что подтверждает результаты исследований авторов (Магомедов, Малютина, Зацепилина, Шапкарина, \& Лыгин, 2016; Могильный \& Шалтумаев, 2017) по применению цельносмолотой муки различных зерновых культур при производстве мучных кондитерских изделий.
Для изучения влияния количественной замены маргарина заменителем молочного жира с омега-3 жирными кислотами, полученного путем энзимной переэтерификации растительных масел (ЗМЖ-ЭП), на показатели качества сдобного печенья проводили пробные лабораторные выпечки тестовых полуфабрикатов, в рецептуре приготовления которых варьировали содержанием ЗМЖЭП, состав которого представлен в Таблице 6.

Жировой продукт характеризуется высоким содержанием моно- и полиненасыщенных жирных кислот (ПНЖК), близким к оптимальному соотношением ПНЖК семейств $\omega-6$ и $\omega-3$ (Таблица 6) (Зайцева, 2013, с. 15), при содержании омега-3 жирных кислот более 1,3 г/100 г ЗМЖ-ЭП. Сохранению ПНЖК способствует присутствие в нем токоферолов в значительных количествах 53,0 \pm $6,0 \mathrm{Mr} / 100$ г.

Жировой продукт вводили в рецептуру в количестве 25, 75 и 100\% от количества маргарина (Таблица 7).

По органолептическим показателям экспериментальные образцы сдобного печенья не уступали контрольному образцу и соответствовали требованиям ГОСТ 24901-2014²3 (Таблица 8).

Таблица 5

Физико-химические показатели образцов сдобного печенья с использованием цельнозерновой пшеничной муки

\begin{tabular}{|c|c|c|c|c|c|}
\hline \multirow[b]{2}{*}{ Показатель } & \multirow{2}{*}{$\begin{array}{c}\text { Норма по } \\
\text { ГОСТ } \\
24901-2014\end{array}$} & \multirow{2}{*}{$\begin{array}{c}\text { Контрольный об- } \\
\text { разец (по традици- } \\
\text { онной рецептуре) }\end{array}$} & \multicolumn{3}{|c|}{ Образец с использованием цельнозерновой муки } \\
\hline & & & $\begin{array}{c}\text { Замена 25\% } \\
\text { муки в/с }\end{array}$ & $\begin{array}{c}\text { Замена } 75 \% \\
\text { муки в/с }\end{array}$ & $\begin{array}{c}\text { Полная заме- } \\
\text { на муки в/с }\end{array}$ \\
\hline $\begin{array}{l}\text { Массовая доля } \\
\text { влаги, \% }\end{array}$ & Не более 16,0 & 8,3 & 7,6 & 6,9 & 6,4 \\
\hline Намокаемость, \% & Не менее 150 & 151 & 139 & 110 & 98 \\
\hline Щелочность, град. & Не более 2,0 & 1,30 & 1,30 & 1,30 & 1,30 \\
\hline
\end{tabular}

${ }^{23}$ ГОСТ 24901-2014. (2019). Печенье. Общие технические условия. М.: Стандартинформ. 
Таблица 6

Характеристика ЗМЖ-ЭП

\begin{tabular}{lc}
\hline \multicolumn{1}{c}{ Наименование показателя } & Значение \\
\hline Насыщенные ЖК & 46,0 \\
Мононенасыщенные ЖК & 36,8 \\
Полиненасыщенные ЖК: & 17,1 \\
$\omega-3: \omega-6$ & $1: 12$ \\
КЧ, мг КОН/г & 0,2 \\
ПЧ, ммоль 1/2 акт. О/кг & 0,6 \\
транс-изомеры: & \\
9-транс 18:1 & - \\
11-транс 18:1 & 0,1 \\
$\Sigma$ токоферолов, мг токо- & $53,0 \pm 6$ \\
феролацетата/100 г & \\
\hline
\end{tabular}

Анализ физико-химических показателей опытных образцов сдобного печенья выявил их полное соответствие регламентируемым значениям. Причем следует отметить, что увеличение содержания ЗМЖ-ЭП в рецептуре тестового полуфабриката способствует повышению показателя намокаемости готового печенья (Таблица 9). Таким образом, применение ЗМЖ-ЭП в составе рецептуры печенья может компенсировать снижение показателя намокаемости, обусловленное использованием цельнозерновой пшеничной муки при условии их совместного применения.
Дегустационная оценка не выявила наличия отрицательных эффектов замены жирового продукта. Сравнительная оценка потребительских характеристик по показателям вкуса, цвета, запаха, внешнего вида экспериментальных образцов установила их идентичность с контрольным. Таким образом, полученные результаты свидетельствуют о возможности замены маргарина ЗМЖ-ЭП в рецептуре сдобного печенья, сохранении высоких органолептических характеристик и регламентируемых физико-химических показателей. К подобным выводам пришли авторы, аргументирующие целесообразность использования ЗМЖ-ЭП в рецептурах хлебобулочных изделий (Зайцева, Белявская \& Юдина, 2013; Зайцева, Юдина, Рубан, Бессонов \& Мехтиев, 2020; Цыганова, Нечаев, Зайцева, Грекова $\&$ Иовлева, 2016), ржаных лепешек (Зайцева, Юдина \& Рубан, 2017), а также сдобного печенья (Матвеева, Юдина, Дешко \& Дудник, 2009).

Для повышения пищевой и биологической ценности разрабатываемого сдобного печенья в состав рецептуры дополнительно вводили спирулину, характеристика которой представлена в таблице 10 (Пучкова, Белявская \& Ломакин, 2008; Алексеенко, Белявская \& Глебова, 2018).

Принимая во внимание специфичность спирулины как ингредиента (прежде всего, насыщенный

Таблица 7

Расход жировых продуктов в экспериментальных образцах сдобного печенья

\begin{tabular}{lcccc}
\hline \multirow{2}{*}{$\begin{array}{l}\text { Расход сырья на 100 г } \\
\text { готовой продукции, г }\end{array}$} & $\begin{array}{c}\text { Контрольный } \\
\text { обрацец (по тради- }\end{array}$ & \multicolumn{2}{c}{ Образцы печенья с использованием ЗМж-ЭП } \\
\cline { 3 - 5 } & циной рецептуре) & $\begin{array}{c}\text { Замена 25\% } \\
\text { маргарина }\end{array}$ & $\begin{array}{c}\text { Замена 75\% } \\
\text { маргарина }\end{array}$ & $\begin{array}{c}\text { Полная } \\
\text { замена маргарина }\end{array}$ \\
\hline Мука пшеничная & 64,35 & 64,35 & 64,35 & 64,35 \\
высшего сорта & 27,61 & 20,71 & 6,90 & 0,00 \\
Маргарин & 0,00 & 6,90 & 20,71 & 27,61 \\
ЗМЖ-ЭП & & & & \\
\hline
\end{tabular}

Таблице 8

Органолептические показатели образцов сдобного печенья, полученные с использованием ЗМЖ-ЭП

\begin{tabular}{|c|c|c|c|c|}
\hline \multirow{2}{*}{ Показатель } & \multirow{2}{*}{$\begin{array}{c}\text { Контрольный обра- } \\
\text { зец (по традицион- } \\
\text { ной рецептуре) }\end{array}$} & \multicolumn{3}{|c|}{ Образцы печенья с использованием ЗМЖ-ЭП } \\
\hline & & $\begin{array}{c}\text { Замена 25\% } \\
\text { маргарина }\end{array}$ & $\begin{array}{c}\text { Замена } 75 \% \\
\text { маргарина }\end{array}$ & $\begin{array}{c}\text { Полная } \\
\text { замена маргарина }\end{array}$ \\
\hline Форма & \multicolumn{4}{|c|}{ Не расплывчатая, без повреждений } \\
\hline Поверхность & \multicolumn{4}{|c|}{ Гладкая } \\
\hline Цвет & \multicolumn{4}{|c|}{ Равномерный, светло-соломенный } \\
\hline Вкус и запах & \multicolumn{4}{|c|}{ Соответствуют вкусу и запаху рецептурных компонентов } \\
\hline Вид в изломе & \multicolumn{4}{|c|}{ Пропеченное, имеет пористую структуру } \\
\hline
\end{tabular}


Таблица 9

Физико-химические показатели образцов сдобного печенья с использованием ЗМЖ-ЭП

\begin{tabular}{|c|c|c|c|c|c|}
\hline \multirow{2}{*}{ Показатель } & \multirow{2}{*}{$\begin{array}{c}\text { Норма по } \\
\text { ГОСТ } \\
24901-2014\end{array}$} & \multirow{2}{*}{$\begin{array}{l}\text { Контрольный образец (по } \\
\text { традиционной рецептуре) }\end{array}$} & \multicolumn{3}{|c|}{ Образцы печенья с использованием ЗМЖ-ЭП } \\
\hline & & & $\begin{array}{c}\text { Замена 25\% } \\
\text { маргарина }\end{array}$ & $\begin{array}{c}\text { Замена } 75 \% \\
\text { маргарина }\end{array}$ & $\begin{array}{l}\text { Полная заме- } \\
\text { на маргарина }\end{array}$ \\
\hline $\begin{array}{l}\text { Массовая доля } \\
\text { влаги, \% }\end{array}$ & $\begin{array}{c}\text { Не бо- } \\
\text { лее } 16,0\end{array}$ & 8,3 & 8,0 & 6,7 & 7,6 \\
\hline Намокаемость, \% & Не менее 150 & 151 & 157 & 169 & 174 \\
\hline Щелочность, град. & Не более 2,0 & 1,30 & 1,29 & 1,29 & 1,29 \\
\hline
\end{tabular}

темно-зеленый цвет, нейтральный вкус), при выборе дозировки ориентировались на результаты ранее проведенных исследований по ее применению при производстве хлебобулочных изделий (Белявская, 2017). При получении сдобного печенья спирулину вносили в количестве $1 \%$ к массе муки.

Учитывая рекомендации Всемирной организации здравоохранения по потреблению соли для профилактики гипертонии и снижения риска развития болезней сердца и инсульта среди взрослого населения скорректировали рецептуру сдобного печенья в сторону сокращения хлорида натрия.

С учетом полученных результатов разработана рецептура сдобного печенья на основе цельнозерновой муки и ЗМЖ-ЭП, с добавлением спирулины. Предложенная рецептура предполагает полную замену маргарина и пшеничной муки высшего сорта.

Полученные изделия имели выраженные вкус и запах, свойственные входящим в рецептуру печенья компонентам. При оценке формы сдобного печенья расплывчатости и вмятин не наблюдалось. Поверхность характеризовалась как шероховатая, с вкраплениями частиц спирулины; цвет - равномер-

Таблица 10

Характеристика Spirulina platensis

\begin{tabular}{lc}
\hline \multicolumn{1}{c}{ Наименование компонента } & Содержание, 100 г \\
\hline Белок, г & 70,00 \\
Фикоцианин, г & 1,90 \\
Никотиновая кислота, мг & 11,80 \\
$\beta$-каротин, мг & 170,00 \\
Пантотеновая кислота, мг & 1,10 \\
Кобаламин, мг & 0,16 \\
Токоферол, мг & 0,19 \\
Тиамин, мг & 5,50 \\
Линолевая кислота, мг & 1235,20 \\
\hline
\end{tabular}

ный, с серо - зеленым оттенком. При характеристике вида в изломе печенья отмечали равномерную пористую структуру без пустот и следов непромеса (Таблица 11).

Таблица 11

Органолептическая характеристика сдобного печенья на основе цельнозерновой муки и ЗМЖ-ЭП с добавлением спирулины

\begin{tabular}{ll}
\hline \multicolumn{1}{c}{ Показатель } & \multicolumn{1}{c}{ Описание } \\
\hline \multirow{2}{*}{ Форма } & Не расплывчатая, без по- \\
& вреждений края \\
Поверхность & Шероховатая, с вкраплениями ча- \\
& стиц спирулины, не подгорелая \\
Цвет & Равномерный, серо-зеленый оттенок \\
Вкус и запах & Выраженные, свойственные вку- \\
& су и запаху, данному виду печенью \\
Вид в изломе & Пропеченное печенье с по- \\
& ристой структурой \\
\hline
\end{tabular}

Физико-химические показатели сдобного печенья соответствуют требованиям ГОСТ 24901-2014, но отмечается снижение показателя намокаемости. В таблице 12 представлены результаты исследований физико-химических показателей экспериментального образца печенья в сравнении с контрольным.

Проведен расчет пищевой ценности разработанного сдобного печенья на основе цельнозерновой пшеничной муки и ЗМЖ-ЭП с добавлением спирулины (Таблица 13).

Как свидетельствуют представленные результаты, использование в рецептуре сдобного печенья цельнозерновой пшеничной муки дает возможность существенно увеличить в нем содержание пищевых волокон $(5,87$ г/100 г продукта), что позволяет позиционировать разработанное сдобное печенье в качестве источника пищевых волокон. 
Таблица 12

Физико-химические показатели качества сдобного печенья, полученного по традиционной и разработанной рецептурам

\begin{tabular}{|c|c|c|c|}
\hline \multirow[b]{2}{*}{ Физико-химические показатели } & \multirow{2}{*}{$\begin{array}{c}\text { Норма по ГОСТ } \\
\text { 24901-2014 }\end{array}$} & \multicolumn{2}{|c|}{ Значение } \\
\hline & & $\begin{array}{c}\text { Контрольный образец } \\
\text { (по традиционной рецептуре) }\end{array}$ & $\begin{array}{c}\text { Печенье по } \\
\text { новой рецептуре }\end{array}$ \\
\hline Массовая доля влаги, \% & Не более 16,0 & 8,3 & 6,9 \\
\hline Намокаемость, \% & Не менее 150 & 151 & 107 \\
\hline Щелочность, град. & Не более 2,0 & 1,3 & 1,3 \\
\hline Массовая доля жира, \% & Не более 40,0 & 16,0 & 23,5 \\
\hline $\begin{array}{l}\text { Массовая доля общего са- } \\
\text { хара (по сахарозе), \% }\end{array}$ & Не более 45,0 & 19,7 & 18,3 \\
\hline Массовая доля золы, \% & Не более 1,0 & 0,59 & 0,93 \\
\hline
\end{tabular}

Таблица 13

Состав сдобного печенья на основе цзельнозерновой пшеничной муки и ЗМЖ-ЭП с добавлением спирулины

\begin{tabular}{lccc}
\hline \multicolumn{1}{c}{ Наименование } & Содержание, в 100 г & Наименование & Содержание, в 100 г \\
\hline Белки & 7,7 & Общий сахар & 18,3 \\
Жиры & 23,5 & Зола & 0,93 \\
Углеводы & 59,3 & Вода & 6,9 \\
Пищевые волокна & 5,87 & Энергетическая ценность, ккал & 468 \\
\hline
\end{tabular}

Исследован групповой состав липидов разработанного сдобного печенья, который представлен глико- и фосфолипидами, моноациал-, диацил- и триацилглицеринами, свободными жирными кислотами и стеринами.

С использованием метода ГЖХ установлено, что в составе жирных кислот липидов разработанного сдобного печенья содержится значительное количество моно- и полиненасыщенных жирных кислот (55\%). По сравнению со сдобным печеньем, полученным по традиционной рецептуре, выявлено наличие $\gamma$-линоленовой кислоты $(\omega-6)$, а также эссенциальной $\alpha$-линоленовой кислоты $(\omega-3)$ в количестве более 1,3 г/100 г жировой фазы, что при использовании жира в составе разработанной рецептуры в количестве $25 \%$ обеспечивает ее присутствие в готовом изделии на уровне источника (более 0,2 г/100 г). Также отмечено десятикратное увеличение содержания эссенциальной линолевой кислоты (Таблица 14).

Результаты анализа минерального состава показывают, что сдобное печенье содержит широкий спектр минеральных веществ и отличается высоким содержанием таких макроэлементов, как калий, кальций, натрий, магний, фосфор и микроэлементов - медь, железо, марганец, цинк, кремний; вы- явлено наличие минорного компонента селена, который обладает иммуномодулирующей и выраженной антиоксидантной активностью (Таблица 15).

Принимая во внимание условия, позволяющие использовать в маркировке пищевой продукции информации об ее отличительных признаках (ТР ТС 022/2011 «Пищевая продукция в части ее маркировки» $\left.{ }^{24}\right)$, произведенное сдобное печенье можно позиционировать как изделие, являющееся источником магния (20\% средней суточной потребности на 100 г) и железа (23\% средней суточной потребности на 100 г) с низким содержанием натрия (пищевой соли, хлорида натрия) (42,3 мг/100 г).

Показатели безопасности (по содержанию свинца, кадмия, мышьяка) разработанного сдобного печенья не превышают допустимых значений (ТР ТС 021/2011 «О безопасности пищевой продукции»).

Таким образом, применение цельнозерновой пшеничной муки, ЗМЖ-ЭП и спирулины в рецептурной комбинации при получении сдобного печенья обеспечивает существенное повышение его пищевой ценности, которое обусловлено уникальным составом применяемых ингредиентов, что нашло отражение в работах, демонстрирующих эффективность их использования при производстве хлебобулочных

${ }_{24}$ TP TC 022/2011. (2018). Пищевая продукция в части ее маркировки. URL: https://docs.cntd.ru/document/902320347 (дата обращения: 14.05.2021). 
Таблица 14

Состав жирных кислот липидов сдобного печенья, полученного по традиционной рецептуре, и на основе цельнозерновой пшеничной муки, ЗМЖ-ЭП с добавлением спирулины

\begin{tabular}{lcc}
\hline \multicolumn{1}{c}{ Наименование жирной кислоты } & $\begin{array}{c}\text { \%, от суммы всех жирных кислот } \\
\text { в контрольном образце } \\
\text { (по традиционной рецептуре) }\end{array}$ & $\begin{array}{c}\text { \%, от суммы всех } \\
\text { жирных кислот в сдобном } \\
\text { печенье по новой рецептуре }\end{array}$ \\
\hline С6:0 Капроновая & 0,456 & - \\
С8:0 Каприловая & 0,995 & 0,205 \\
С10:0 Каприновая & 1,158 & 2,522 \\
С12:0 Лауриновая & 0,614 & 1,544 \\
С14:0 Миристиновая & 1,402 & - \\
С14:1 Миристолеиновая & 1,802 & 0,046 \\
С15:0 Пентадекановая & - & 34,739 \\
С16:0 Пальмитиновая & 23,584 & 0,139 \\
С16:1 цис-9-Пальмитолеиновая & 0,217 & 0,098 \\
С17:0 Гептадкановая & - & 4,677 \\
С18:0 Стеариновая & 9,745 & 34,745 \\
С18:1 цис-9-Олеиновая & 57,879 & 18,942 \\
18:2 цис-9,12-линолевая & 1,845 & 0,370 \\
С20:0 Арахиновая & 0,769 & 0,131 \\
С18:3 цис-9,12,15-гамма Линоленовая & - & 0,186 \\
С20:1 цис-11-Гондоиновая & 0,936 & 1,317 \\
С18:3 цис-9,12,15 Линоленовая & - & 0,155 \\
С22:0 Бегеновая & - & - \\
\hline
\end{tabular}

Таблица 15

Минеральный состав сдобного печенья по разработанной рецептуре

\begin{tabular}{lccc}
\hline Наименование элемента & Содержание, мг/кг & Наименование элемента & Содержание, мг/кг \\
\hline Серебро & 0,0081 & Литий & 0,6630 \\
Алюминий & 1,4558 & Магний & 802,00 \\
Кальций & 264,94 & Марганец & 19,0947 \\
Кобальт & 0,0054 & Натрий & 423,00 \\
Хром & 0,0747 & Никель & 0,2655 \\
Медь & 1,7832 & Фосфор & 22,55 \\
Железо & 32,11 & Сера & 1,0648 \\
Калий & 1698,00 & Сурьма & 1,1203 \\
Кремний & 2,1103 & Стронций & 1,0644 \\
Ванадий & 0,0029 & Цинк & 18,58 \\
Кадмий & 0,0178 & Свинец & 0,2705 \\
Мышьяк & 0,0078 & Селен & 0,0007 \\
\hline
\end{tabular}

и мучных кондитерских изделий (Талейсник, Щербакова, Герасимов \& Мизинчикова, 2019; Белявская, 2017; Зайцева, Белявская, \& Юдина, 2013; Зайцева, Юдина, Рубан, Бессонов, \& Мехтиев, 2020; Цыганова, Нечаев, Зайцева, Грекова, \& Иовлева, 2016; Зайцева, Юдина, \& Рубан, 2017; Матвеева, Юдина, Дешко, \& Дудник, 2009).

\section{Выводы}

В результате проведенных исследований разработаны рецептура и технологические решения по получению сдобного печенья на основе цельнозерновой пшеничной муки и жирового продукта энзимной перетерификации с омега-3 жирными 
кислотами с добавлением спирулины. Получены результаты, демонстрирующие влияние выбранных ингредиентов на органолептические, физико-химические показатели сдобного печенья и его пищевую ценность. Показано, что усовершенствованная рецептура позволяет получать сдобное печенье с достойными потребительскими свойствами, по физико-химическим показателям соответствующее требованиям ГОСТ 24901-2014 при некотором снижении показателя намокаемости. При этом печенье по новой рецептуре по сравнению с традиционным изделием характеризуется повышенной пищевой ценностью (источник омега-3 жирных кислот, пищевых волокон, магния и железа) и позволяет расширить ассортиментную линейку сдобного печенья.

Разработан комплект ТД (ТУ, ТИ) (проект) на новое обогащенное сдобное печенье.

\section{Литература}

Алексеенко, Е. В., Белявская, И. Г., \& Глебова, П. С. (2019). Перспективные ингредиенты для получения сдобного печенья повышенной пищевой ценности. В Кондитерские изделия XXI века: Материалы докладов ХІІ Международной конференции (с. 52-62). М.: Международная промышленная академия.

Белявская, И. Г. (2017). Хлебобулочные изделия функционального назначения с использованием микроводоросли спирулины. Кондитерское и хлебопекарное производство, 9-10, 17-19.

Бессмертная, И. А., \& Васильченко, Н. В. (2018). Некоторые аспекты технологии печенья из смеси пшеничной и спельтовой муки. В Материалы VI Международного Балтийского морского форума (с. 31-37). Калининград: Изд-во КГТУ.

Бобылева, А. В. (2018). Перспективы использования нетрадиционного растительного сырья в производстве мучных кондитерских изделий функционального назначения. Евразийское научное объединение, 12-1, 63-67.

Гайсина, В. А., Козубаева, Л. А., \& Кузьмина, С. С. (2017). Пищевая ценность сдобного печенья с подсолнечной мукой. Ползуновский вестник, 2, 19-22.

Дерканосова, Н. М., Курчаева, Е. Е., Пащенко, В. Л., \& Калашникова, С. В. (2018). Использование композитных смесей функциональной направленности в производстве печенья. Вестник Воронежского государственного аграрного университета, 2, 116-123. https://doi.org/10.17238/issn2071-2243.2018.2.116

Журавская, А. В., \& Васюкова, А. Т. (2019). Использование пищевых волокон в производстве сдобного печенья. В Тенденции развития ту- ризма и гостеприимства в России: Материалы Всероссийской студенческой научной конференции (с. 499-504). М.: Изд-во ГЦОЛИФК.

Зайцева, Л. В., Белявская, И. Г., \& Юдина, Т. А. (2013). Применение переэтерифицированных жиров в технологии хлебобулочных изделий. М.: МГУПП.

Зайцева, Л. В., Юдина, Т. А., \& Рубан, Н. В. (2017). Качество ржаных лепешек с добавлением муки чиа и масложирового продукта энзимной переэтерификации. Хранение и переработка сельхозсырья, 5, 31-34.

Зайцева, Л. В., Юдина, Т. А., Рубан, Н. В., Бессонов, В. В., \& Мехтиев, В. С. (2020). Современные подходы к разработке рецептур безглютеновых хлебобулочных изделий. Вопросы питания, 89(1), 77-85.

Иванова, О. В. (2019). Экспертиза качества печенья сдобного, выработанного с применением муки гречневой. В Вклад молодых ученых в аграрную науку: Материаль международной научно-практической конференции (с. 508-511). Кинель: Изд-во СГСА.

Захарова, А. С., Козубаева, Л. А., \& Егорова, Е. Ю. (2019). Мучные кондитерские изделия с брусникой. Ползуновский вестник, 4, 17-20. https://oi. org/10.25712/ASTU.2072-8921.2019.04.004

Захарова, А. С., Кузьмина, С. С., \& Егорова, Е. Ю. (2020). Использование дикорастущего сырья Алтайского края при производстве печенья. Ползуновский вестник, 2, 12-17. https://doi.org/10.25712/ ASTU.2072-8921.2020.02.003

Калинкина, Н. О., \& Егорова, Е. Ю. (2019). Обогащение сдобного печенья белком и пищевыми волокнами. Ползуновский вестник, 1, 17-22. https://doi. org/10.25712/ASTU.2072-8921.2019.01.003

Киселева, М. Ю., \& Насырова, Ю. Г. (2017). Влияние инулинсодержащего сырья на качество печенья сдобного. Успехи современной науки, 11, 221-224.

Клочко, А. В., Короткова, Т. Г., \& Ксандопуло, С. Ю. (2017). Использование порошка из виноградных выжимок при производстве мучных кондитерских изделий. КубГАУ, 129, 381-390.

Колбина, А. Ю. (2018). Технология производства сдобного печенья с натуральными растительными добавками. В Аграрная наука в инновационном развитии АПК: Сборник научных статей международного молодежного аграрного форума (с. 119-126). Мичуринск: Изд-во МГАУ.

Кравченко, Л. В., Гладких, О. Л., \& Гмошинский, И. В. (2005). Сравнительное изучение антиоксидантных свойств фикоцианина и селенфикоцианина в модельных системах окисления. В Материалы IX Международного съезда Фитофарм (с. 161). СПб.

Кузьмина, С. С., Козубаева, Л. А., \& Гайсина, В. А. (2015). Перспективы использования кедровой муки при производстве сдобного печенья. Вестник Алтайской науки, 1, 415-418. 
Лаптева, Н. К., \& Митькиных, Л. В. (2013). Оптимальное соотношение пшеничной, ржаной и тритикалевой муки в производстве сдобного печенья. Аграрная наука Евро-Северо- Востока, 3, 3538.

Магомедов, Г. О., Малютина, Т. Н., Зацепилина, Н. П., Шапкарина, А. И., \& Лыгин, В. В. (2016). Использование тритикалевой муки в производстве песочно-сдобного печенья. Кондитерское производство, 5, 38-40.

Матвеева, И. В., Юдина, Т. А., Дешко, О. В., \& Дудник, Е. Е. (2009). Новый жировой продукт для производства сдобного печенья. Хлебопечение России, 6, 20-21.

Матвеева, Т. В., \& Корячкина, С. Я. (2011). Мучные кондитерские изделия функционального назначения. Научные основы, технологии, рецептуры. Орел: ФГОУ ВПО «Госуниверситет - УНПК».

Меренкова, С. П., \& Полякова, Е. Л. (2018). Экспериментальное обоснование применения ягодного сырья в технологии обогащенных мучных кондитерских изделий. Вестник Южно-Уральского государственного университета, 2, 20-29. https:// doi.org/10.14529/food180203

Могильный, М. П., \& Шалтумаев, Т. Ш. (2014). Роль рецептурных компонентов в повышении качества мучных кондитерских изделий. Известия высших учебных заведений. Пищевая технология, 2, 63-66.

Назимова, Е. В., Захаренко, М. А., \& Марков, А. С. (2020). Применение продуктов переработки шиповника в производстве сдобного печенья. В Инновационные технологии пищевых производств: Сборник тезисов докладов II Всероссийской научно-практической конференции студентов, аспирантов и молодых ученых (с. 46). Севастополь: Изд-во ФГАОУ ВО СГУ.

Пучкова, Л. И., Белявская, И. Г., \& Ломакин, А. А. (2008). Повышение пищевой ценности хлеба на основе биологически активной добавки микроводоросли спирулина альга ляменсис алакрис. В Сборник материалов VI Международной научно-практической конференции (ч. 2, с. 302-307). М.: МГУПП.

Резниченко, И. Ю., \& Устинова, Ю. В. (2020). Новые тенденции в технологии мучных кондитерских изделий функциональной направленности. В Актуальные направления научных исследований: Технологии, качество и безопасность: Сборник материалов Национальной (Всероссийской) конференции (с. 99-101). Кемерово: Изд-во КГУ.

Ромай, Г., Гонсалес, Р., Ледон, Н., Ремирес, Д., \& Римбау, В. (2003). Фикоцитин: Билинпротеин с антиоксидантным, противовоспалительным и ней- ропротективным действием. Нынешняя наука о белках и пептидах, 4, 207-216.

Талейсник, М. А., Щербакова, Н. А., Герасимов, Т. В., \& Мизинчикова, И. И. (2019). Принципы создания специализированного сахарного печенья для детского питания. Научные труды КубГТУ, 9, 217-224.

Тертычная, Т. Н., Мажулина, И. В., Горбунова, Е. А., \& Синельникова, О. В. (2019). Натуральные биологически активные добавки при производстве сдобного печенья. Известия Тимирязевской сельскохозяйственной академии, 1, 127-137.

Хлюдзинская, Е. В. (2019). Анализ воздействия пшеничной и гречневой муки на основные показатели свойств сдобного печенья. В Молодежь и наука: шаг к успеху: Сборник научных статей 3-й Всероссийской научной конференции перспективных разработок молодых ученых (с. 260-263). Курск: Изд-во ЗАО «Университетская книга».

Цыганова, Т. Б., Нечаев, А. П., Зайцева, Л. В., Грекова, А. Ю., \& Иовлева, К. В. (2016). Влияние жировых продуктов на качество и сохранение свежести сдобных хлебобулочных изделий длительного хранения. Хлебопродукты, 7, 60-63.

Шабурова, Г. В., \& Кулькова, Ю. С. (2019). Применение овсяных отрубей и овощного сырья в рецептуре сдобного печенья. Инновационная техника и технология, 3, 36-41.

Шпис, А. А., \& Шпис, А. Н. (2016). Использование облепихового порошка при производстве сдобного печенья в ИП Радченко. В Приоритетные направления развития пищевой индустрии: Сборник научных статей конференции (с. 655-658). Ставрополь: Издво СГАУ.

Morsy, O. M., Sharoba, A. M., EL-Desouky, A. I., Bahlol, H. E. M., \& Abd El Mawla, E. M. (2014). Production and evaluation of some extruded food products using Spirulina algae. Annals of Agricultural Science, Moshtohor, 52(4), 495-510.

Petrova, M., \& Zhateva, D. (2018). Spirulina algae as a source of phytonutrients for food enrichment. В Церевитинские чтения- 2018: Материаль V Международной конференции (с. 50-53). М.: Изд-во РЭУ им. Г.В. Плеханова.

Smertina, E., Fedyanina, L., Lyakh, V., Chadova, T., \& Vershinina, A. (2016). Modern tendencies and prospects of using Algae as an ingredient for bakery products. Research Journal of Pharmaceutical, Biological and Chemical Sciences, 2, 989-997.

Soni, R. A., Sudhakar, K., \& Rana, R. S. (2017). Spirulina from growth to nutritional product: A review. Trends in Food Science \& Technologe, 69(A), 157-171. https:// doi.org/10.1016/j.tifs.2017.09.010 


\title{
Butter Cookies of High Nutritional Value
}

\author{
Elena V. Alekseenko \\ Moscow State University of Food Production \\ 11, Volokolamskoe highway, Moscow, 125080, \\ E-mail:alekseenkoEV@mgupp.ru \\ Irina G. Belyavskaya \\ Moscow State University of Food Production \\ 11, Volokolamskoe highway, Moscow, 125080 \\ E-mail: Belyavskaya@mgupp.ru
}

Larisa V. Zaitseva

VNIKP is a branch of FGBNU «FNTS of food systems after V.M. Gorbatov» RAS p. 3, bld. 20, Elektrozavodskaya str., Moscow, 107023

E-mail:lvz2360@mail.ru

\author{
Anna G. Uvarova \\ Kursk State Agricultural Academy named after I.I. Ivanov \\ 70, Karl Marx str., Kursk, 305021 \\ Email:A.G.Uvarova@yandex.ru
}

\begin{abstract}
The priority direction in the development of new types of butter cookies is the modification of traditional recipes and the use of innovative ingredients that increase the nutritional value of finished products and form their functional orientation. A complex of studies on experimental substantiation, formulation development and technological solutions was carried out in order to obtain butter cookies of increased nutritional value based on wheat flour from whole-ground grain and a fat product of enzyme transesterification with omega- 3 fatty acids with the addition of spirulina microalgae. The influence of the selected ingredients on the organoleptic, physico-chemical parameters and nutritional value of the finished products was studied. It is shown that the developed type of butter cookies has decent consumer properties, in terms of physical and chemical parameters-meets the requirements of GOST 24901-2014 with a slight decrease in the wetness index. It is proved that the developed product is characterized by an improved lipid profile: the composition of fatty acids contains a significant amount of unsaturated fatty acids (55\%), compared with the butter cookies obtained according to the traditional recipe, the presence of $\omega-6$ $\gamma$-linolenic acid is revealed, there is a tenfold increase in the content of essential $\omega$ - 6 linoleic acid; cookies can be positioned as a product that is a source of essential omega- 3 fatty acids (alpha-linolenic more than $0.2 \mathrm{~g} / 100 \mathrm{~g}$ ). It was found that the butter cookies obtained according to the improved recipe are a source of dietary fiber (5.87 $\mathrm{g} / 100 \mathrm{~g}$ of the product), magnesium (20\% of the average daily requirement per $100 \mathrm{~g}$ ) and iron (23\% of the average daily requirement per $100 \mathrm{~g}$ ) with a low content of sodium (salt) $(42.3 \mathrm{mg} / 100 \mathrm{~g})$. Developed a set of TD (TU, TI) (project) for a new enriched butter cookies.
\end{abstract}

Keywords: butter cookies, whole wheat flour, fat product of enzyme transesterification, spirulina, organoleptic and physico-chemical parameters, nutritional value

\section{References}

Alekseenko, E. V., Belyavskaya, I. G., \& Glebova, P. S. (2019). Perspektivnye ingredienty dlya polucheniya sdobnogo pechen'ya povyshennoi pishchevoi tsennosti [Promising ingredients for obtaining rich cookies of increased nutritional value]. In Materialy dokladov XII Mezhdunarodnoi konferentsii «Konditerskie izdeliya XXI veka» [Proceedings of XII international conference "Confectionery products of the 21th century"] (pp. 52-62). Moscow: Mezhdunarodnaya promyshlennaya akademiya.

Belyavskaya, I. G. (2017). Khlebobulochnye izdeliya funktsional'nogo naznacheniya $\mathrm{s}$ ispol'zovaniem mikrovodorosli spiruliny [Functional bakery products with the use of microalgae spi- 
rulina]. Konditerskoe i khlebopekarnoe proizvodstvo [Confectionery and Bakery Production], 9-10, 17-19.

Bessmertnaya, I. A., \& Vasil'chenko, N. V. (2018). Nekotorye aspekty tekhnologii pechen'ya iz smesi pshenichnoi i spel'tovoi muki [Some aspects of the technology of cookies made from a mixture of wheat and spelt flour]. In Materialy VI Mezhdunarodnogo Baltiiskogo morskogo foruma [Proceedings of the 6th International Baltic Sea Forum] (pp. 31-37). Kaliningrad: Izd-vo KGTU.

Bobyleva, A. V. (2018). Perspektivy ispol'zovaniya netraditsionnogo rastitel'nogo syr'ya v proizvodstve muchnykh konditerskikh izdelii funktsional'nogo naznacheniya [Prospects for the use of non-traditional vegetable raw materials in the production of flour confectionery products for functional purposes]. Evraziiskoe nauchnoe ob"edinenie [Eurasian Scientific Association], 12-1, 63-67.

Gaisina, V. A., Kozubaeva, L. A., \& Kuz'mina, S. S. (2017). Pishchevaya tsennost' sdobnogo pechen'ya s podsolnechnoi mukoi [Nutritional value of butter cookies with sunflower flour]. Polzunovskii vestnik [Polzunovsky Bulletin], 2, 19-22.

Derkanosova, N. M., Kurchaeva, E. E., Pashchenko, V. L., \& Kalashnikova, S. V. (2018). Ispol'zovanie kompozitnykh smesei funktsional'noi napravlennosti $v$ proizvodstve pechen'ya [The use of functional composite mixtures in the production of cookies]. Vestnik Voronezhskogo gosudarstvennogo agrarnogo universiteta [Bulletin of the Voronezh State Agrarian University], 2, 116-123. https://doi.org/10.17238/ issn2071-2243.2018.2.116

Zhuravskaya, A. V., \& Vasyukova, A. T. (2019). Ispol'zovanie pishchevykh volokon $\mathrm{v}$ proizvodstve sdobnogo pechen'ya [The use of dietary fiber in the production of butter cookies]. In Materialy Vserossiiskoi studencheskoi nauchnoi konferentsii «Tendentsii razvitiya turizma i gostepriimstva $v$ Rossii» [Proceedings of the All-Russian Student Scientific Conference "Trends in the development of Tourism and Hospitality in Russia"] (pp. 499-504). Moscow: Izd-vo GTsOLIFK.

Zaitseva, L. V., Belyavskaya, I. G., \& Yudina, T. A. (2013). Primenenie pereeterifitsirovannykh zhirov $v$ tekhnologii khlebobulochnykh izdelii [The Use of Transesterified Fats in the Technology of Bakery Products]. Moscow: MGUPP.

Zaitseva, L. V., Yudina, T. A., \& Ruban, N. V. (2017). Kachestvo rzhanykh lepeshek s dobavleniem muki chia i maslozhirovogo produkta enzimnoi pereeterifikatsii [Quality of rye tortillas with the addition of chia flour and fat-and-oil product of enzyme transesterification]. Khranenie $i$ pererabotka sel'khozsyr'ya [Storage and Processing of Agricultural Raw Materials], 5, 31-34.
Zaitseva, L. V., Yudina, T. A., Ruban, N. V., Bessonov, V. V., \& Mekhtiev, V. S. (2020). Sovremennye podkhody k razrabotke retseptur bezglyutenovykh khlebobulochnykh izdelii [Modern approaches to the development of recipes for gluten-free bakery products]. Voprosy pitaniya [Nutrition Issues], 89(1), 77-85.

Ivanova, O. V. (2019). Ekspertiza kachestva pechen'ya sdobnogo, vyrabotannogo s primeneniem muki grechnevoi [Examination of the quality of butter cookies produced with the use of buckwheat flour]. In Materialy mezhdunarodnoi nauchno-prakticheskoi konferentsii «Vklad molodykh uchenykh $v$ agrarnuyu nauku» [Proceedings of the international scientific and practical conference "Contribution of young scientists to agricultural science"] (pp. 508511). Kinel': Izd-vo SGSA.

Zakharova, A. S., Kozubaeva, L. A., \& Egorova, E. Yu. (2019). Muchnye konditerskie izdeliya s brusnikoi [Flour confectionery products with lingonberries]. Polzunovskii vestnik [Polzunovsky Bulletin], 4, 17-20. https://doi.org/10.25712/ASTU.20728921.2019.04.004

Zakharova, A. S., Kuz'mina, S. S., \& Egorova, E. Yu. (2020). Ispol'zovanie dikorastushchego syr'ya Altaiskogo kraya pri proizvodstve pechen'ya [The use of wild raw materials of the Altai Territory in the production of cookies]. Polzunovskii vestnik [Polzunovsky Bulletin], 2, 12-17. https://doi.org/10.25712/ASTU.20728921.2020.02.003

Kalinkina, N. O., \& Egorova, E. Yu. (2019). Obogashchenie sdobnogo pechen'ya belkom i pishchevymi voloknami [Enriching butter cookies with protein and dietary fiber]. Polzunovskii vestnik [Polzunovsky Bulletin], 1, 17-22. https://doi. org/10.25712/ASTU.2072-8921.2019.01.003

Kiseleva, M. Yu., \& Nasyrova, Yu. G. (2017). Vliyanie inulinsoderzhashchego syr'ya na kachestvo pechen'ya sdobnogo [Influence of inulin-containing raw materials on the quality of butter cookies]. Uspekhi sovremennoi nauki [Achievements of Modern Science], 11, 221-224.

Klochko, A. V., Korotkova, T. G., \& Ksandopulo, S. Yu. (2017). Ispol'zovanie poroshka iz vinogradnykh vyzhimok pri proizvodstve muchnykh konditerskikh izdelii [The use of grape pomace powder in the production of flour confectionery products]. KubGAU [Kuban State Agrarian University], 129, 381-390.

Kolbina, A. Yu. (2018). Tekhnologiya proizvodstva sdobnogo pechen'ya s natural'nymi rastitel'nymi dobavkami [Technology of production of butter cookies with natural vegetable additives]. In Sbornik nauchnykh statei mezhdunarodnogo molodezhnogo agrarnogo foruma «Agrarnaya nauka $v$ innovatsionnom razvitii APK» [Collection of scientific articles of the international Youth Agrarian Forum 
"Agricultural science in the innovative development of the agro-industrial complex"] (pp. 119-126). Michurinsk: Izd-vo MGAU.

Kravchenko, L. V., Gladkikh, O. L., \& Gmoshinskii, I. V. (2005). Sravnitel'noe izuchenie antioksidantnykh svoistv fikotsianina i selenfikotsianina $\mathrm{v}$ model'nykh sistemakh okisleniya [Comparative study of the antioxidant properties of phycocyanin and selenphycocyanin in model oxidation systems]. In Materialy IX Mezhdunarodnogo s"ezda Fitofarm [Proceedings of the 9th International Congress of Phytopharm] (p. 161). S-Petersburg.

Kuz'mina, S. S., Kozubaeva, L. A., \& Gaisina, V. A. (2015). Perspektivy ispol'zovaniya kedrovoi muki pri proizvodstve sdobnogo pechen'ya [Prospects for the use of cedar flour in the production of butter cookies]. Vestnik Altaiskoi nauki [Bulletin of the Altai Science], 1, 415-418.

Lapteva, N. K., \& Mit'kinykh, L. V. (2013). Optimal'noe sootnoshenie pshenichnoi, rzhanoi i tritikalevoi muki v proizvodstve sdobnogo pechen'ya [The optimal ratio of wheat, rye and tritical flour in the production of butter cookies]. Agrarnaya nauka Evro-Severo-Vostoka [Agricultural Science of the Euro-North-East], 3, 35-38.

Magomedov, G. O., Malyutina, T. N., Zatsepilina, N. P., Shapkarina, A. I., \& Lygin, V. V. (2016). Ispol'zovanie tritikalevoi muki v proizvodstve pesochno-sdobnogo pechen'ya [The use of triticalic flour in the production of shortbread cookies]. Konditerskoe proizvodstvo [Confectionery and bakery production], 5, 38-40.

Matveeva, I. V., Yudina, T. A., Deshko, O. V., \& Dudnik, E. E. (2009). Novyi zhirovoi produkt dlya proizvodstva sdobnogo pechen'ya [A new fat product for the production of butter cookies]. Khlebopechenie Rossii [Bread Making in Russia], 6, 20-21.

Matveeva, T. V., \& Koryachkina, S. Ya. (2011). Muchnye konditerskie izdeliya funktsional'nogo naznacheniya. Nauchnye osnovy, tekhnologii, retseptury [Flour confectionery products for functional purposes. Scientific bases, technologies, recipes]. Orel: FGOU VPO «Gosuniversitet - UNPK».

Merenkova, S. P., \& Polyakova, E. L. (2018). Eksperimental'noe obosnovanie primeneniya yagodnogo syr'ya $\mathrm{v}$ tekhnologii obogashchennykh muchnykh konditerskikh izdelii [Experimental substantiation of the use of berry raw materials in the technology of enriched flour confectionery products]. Vestnik Yuzhno-Ural'skogo gosudarstvennogo universiteta [Bulletin of the South Ural State University], 2, 20-29. https://doi. org/10.14529/food 180203

Mogil'nyi, M. P., \& Shaltumaev, T. Sh. (2014). Rol' retsepturnykh komponentov $\mathrm{v}$ povyshenii kachestva muchnykh konditerskikh izdelii [The role of prescription components in improving the quality of flour confectionery products]. Izvestiya vysshikh uchebnykh zavedenii. Pishchevaya tekhnologiya [News of Higher Educational Institutions. Food Technology], 2, 63-66.

Nazimova, E. V., Zakharenko, M. A., \& Markov, A. S. (2020). Primenenie produktov pererabotki shipovnika $\mathrm{V}$ proizvodstve sdobnogo pechen'ya [Application of rosehip processing products in the production of butter cookies]. In Sbornik tezisov dokladov II Vserossiiskoi nauchno-prakticheskoi konferentsii studentov, aspirantov i molodykh uchenykh «Innovatsionnye tekhnologii pishchevykh proizvodstv» [Collection of abstracts of the 2nd All-Russian scientific and Practical Conference of students, postgraduates and Young scientists "Innovative technologies of food production"] (p. 46). Sevastopol': Izd-vo FGAOU VO SGU.

Puchkova, L. I., Belyavskaya, I. G., \& Lomakin, A. A. (2008). Povyshenie pishchevoi tsennosti khleba na osnove biologicheski aktivnoi dobavki mikrovodorosli spirulina al'ga lyamensis alakris [Increasing the nutritional value of bread based on a dietary supplement microalgae spirulina alga lamensis alacris]. In Sbornik materialov VI Mezhdunarodnoi nauchno-prakticheskoi konferentsii [Proceedings of the 6th International Scientific and Practical Conference] (vol. 2, pp. 302-307). Moscow: MGUPP.

Reznichenko, I. Yu., \& Ustinova, Yu. V. (2020). Novye tendentsii $\mathrm{v}$ tekhnologii muchnykh konditerskikh izdelii funktsional'noi napravlennosti [New trends in the technology of flour confectionery products of functional orientation]. In Sbornik materialov Natsional'noi (Vserossiiskoi) konferentsii "Aktual'nye napravleniya nauchnykh issledovanii: Tekhnologii, kachestvo i bezopasnost'» [Proceedings of the National (All-Russian) Conference "Current directions of scientific research: Technologies, Quality and Safety”] (pp. 99-101). Kemerovo: Izdvo KGU.

Romai, G., Gonsales, R., Ledon, N., Remires, D., \& Rimbau, V. (2003). Fikotsitin: Bilinprotein s antioksidantnym, protivovospalitel'nym i neiroprotektivnym deistviem [Phycocytin: Bilinprotein with antioxidant, anti-inflammatory and neuroprotective effects]. Nyneshnyaya nauka o belka$k h$ i peptidakh [The Current Science of Proteins and Peptides], 4, 207-216.

Taleisnik, M. A., Shcherbakova, N. A., Gerasimov, T. V., \& Mizinchikova, I. I. (2019). Printsipy sozdaniya spetsializirovannogo sakharnogo pechen'ya dlya detskogo pitaniya [Principles of creating specialized sugar cookies for baby food]. Nauchnye trudy KubGTU [Scientific Works Kuban State Technological University], 9, 217-224. 
Tertychnaya, T. N., Mazhulina, I. V., Gorbunova, E. A., \& Sinel'nikova, O. V. (2019). Natural'nye biologicheski aktivnye dobavki pri proizvodstve sdobnogo pechen'ya [Natural biologically active additives in the production of butter cookies]. Izvestiya Timiryazevskoi sel'skokhozyaistvennoi akademii [News of the Timiryazev Agricultural Academy], 1, 127-137.

Khlyudzinskaya, E. V. (2019). Analiz vozdeistviya pshenichnoi i grechnevoi muki na osnovnye pokazateli svoistv sdobnogo pechen'ya [Analysis of the impact of wheat and buckwheat flour on the main indicators of the properties of butter cookies]. In Sbornik nauchnykh statei 3-i Vserossiiskoi nauchnoi konferentsii perspektivnykh razrabotok molodykh uchenykh «Molodezh' i nauka: shag $k$ uspekhu» [Compilation of scientific articles of the 3rd All-Russian Scientific Conference of Promising Developments of Young Scientists "Youth and Science: A step to success”] (pp. 260-263). Kursk: Izd-vo ZAO «Universitetskaya kniga».

Tsyganova, T. B., Nechaev, A. P., Zaitseva, L. V., Grekova, A. Yu., \& Iovleva, K. V. (2016). Vliyanie zhirovykh produktov na kachestvo i sokhranenie svezhesti sdobnykh khlebobulochnykh izdelii dlitel'nogo khraneniya [The influence of fat products on the quality and freshness of long-term bakery products]. Khleboprodukty [Bread Products], 7, 60-63.

Shaburova, G. V., \& Kul'kova, Yu. S. (2019). Primenenie ovsyanykh otrubei i ovoshchnogo syr'ya v retsepture sdobnogo pechen'ya [The use of oat bran and vegetable raw materials in the recipe of butter cookies]. Innovatsionnaya tekhnika $i$ tekhnologiya [Innovative Equipment and Technology], 3, 36-41.

Shpis, A. A., \& Shpis, A. N. (2016). Ispol'zovanie oblepikhovogo poroshka pri proizvodstve sdobnogo pechen'ya v IP Radchenko [The use of sea buckthorn powder in the production of butter cookies in IP Radchenko]. In Sbornik nauchnykh statei konferentsii «Prioritetnye napravleniya razvitiya pishchevoi industrii» [Compilation of scientific articles of the conference "Priority directions of development of the food industry"] (pp. 655-658). Stavropol': Izdvo SGAU.

Morsy, O. M., Sharoba, A. M., EL-Desouky, A. I., Bahlol, H. E. M., \& Abd El Mawla, E. M. (2014). Production and evaluation of some extruded food products using Spirulina algae. Annals of Agricultural Science, Moshtohor, 52(4), 495-510.

Petrova, M., \& Zhateva, D. (2018). Spirulina algae as a source of phytonutrients for food enrichment. In Materialy V Mezhdunarodnoi konferentsii «Tserevitinskie chteniya- 2018» [Proceedings of the 5th International Conference "Tserevitinsky Readings-2018”] (pp. 50-53). Moscow: Izd-vo REU im. G.V. Plekhanova.

Smertina, E., Fedyanina, L., Lyakh, V., Chadova, T., \& Vershinina, A. (2016). Modern tendencies and prospects of using Algae as an ingredient for bakery products. Research Journal of Pharmaceutical, Biological and Chemical Sciences, 2, 989-997.

Soni, R. A., Sudhakar, K., \& Rana, R. S. (2017). Spirulina from growth to nutritional product: A review. Trends in Food Science \& Technologe, 69(A), 157-171. https://doi.org/10.1016/j.tifs.2017.09.010 